\title{
Analysis of Physical and Chemical Properties of Some Selected Soils of Rain Forest Zones of Delta State, Nigeria
}

\author{
Umeri C*, Onyemekonwu RC and Moseri H \\ Department of Agricultural Science Education, College of Education, Nigeria
}

Submission: March 03, 2017; Published: April 05, 2017

"Corresponding author: Umeri C, Department of Agricultural Science Education, College of Education, Agbor, Delta State, Nigeria, Email: chukwukaraymond@gmail.com

\begin{abstract}
This study was conducted to evaluate the physical and chemical properties of some selected soils of rain forest zones in Delta State; Latitude 50 and 60 and 30' North and longitude 50 and 60,45' east. Hence, representative soil samples were obtained from four locations viz: Abraka, Sapele, Mosogar, Aghalokpe (Rainforest zone) at $0-15 \mathrm{~cm}$ and $15-30 \mathrm{~cm}$ depths. These were analyzed for their physical and chemical properties. The soils studied were mainly sand and loamy sand, with sandy texture predominating. The soils had a pH range of 4.72 to 6.52 at the surface, and were marginal inorganic carbon, total nitrogen, exchangeable $\mathrm{Ca}, \mathrm{Mg}$, and ECEC. Zinc, Fe, $\mathrm{Cu}$ and Mn contents were found to be adequate based on established critical levels for the various nutrients. Potassium levels were found to be deficient in the soils.
\end{abstract}

Keywords: Physical properties; Chemical properties; Selected soils; Delta state; Nigeria

\section{Introduction}

Nature of parent material has been found to influence development and characteristics of soils. The ability of a soil to support plant growth depends on its physical and biological properties which have been found to play significant roles in crop production. A soil that supplies adequate nutrients needed by plants with favorable soil $\mathrm{pH}$ will produce better crops quality and yield if other conditions of growth such as biological and physical properties of the soil are favorable. The quality of soils does not depend on its ability to supply adequate nutrients alone but the nutrients must be in the right proportion as needed by plants [1]. The declining soil fertility have been reported as a major limitation to increasing yields, and a threat to sustainability of crops [2] is the need to take the inventory of their nutrient status in the soils. A good knowledge of the variations of soil physical - chemical properties as it relates to micronutrient status is essential for good land evaluation which is a pre-requisite for sound land use planning. Moreover, information on the profile distribution of these elements in arable crop growing soils will provide the basis for making informed decision with respect to fertilization and other soil management practices. The broad objective of the study was to evaluate the physical and chemical properties of some selected soils in rain forest zone of Delta State. The specific objectives were to a. Identify the physical properties of some selected soils in rain forest zone of Delta State. b. Identify the chemical properties of some selected soils in rain forest zone of Delta State.

c. Examine the micro nutrient of some selected soils in rain forest zone of Delta State.

\section{Materials and Methods}

The study was carried out in Abraka, Sapele Mosogar and Aghalokpe in the rain forest zone of Delta State, which lies between longitude $8^{\circ} 201$ and $8^{\circ} 301$ East of the equator. Rainfall occurs mainly between April and October. Annual rainfall is usually between $2000 \mathrm{~mm}-3000 \mathrm{~mm}$ with an intense sunlight, which lasts for a minimum of 8 hours daily. Temperatures are high for most parts of the year, especially in the months of November to April with a mean monthly of $31 \mathrm{oC}$. The annual range of temperature is thus small only varying between $3{ }^{\circ} \mathrm{C}$ and $5{ }^{\circ} \mathrm{C}$. Relative humidity varies from $90 \%$ during rains to about $60 \%$ in dry season [3].

There are three types of soils in Delta state. These consist of alluvial soils on the marine deposits along the coast, alluvial and hydro morphic soils on marine and lacustrine deposits found in the area close to the Niger and Benin Rivers and the feral soils on loose sandy sediments in the dry land area of the north and north east [4].

The climatic conditions of Delta State are similar to other parts of Southern Nigeria. There are two distinct seasons; the dry season 
and the rainy season [5]. The rainy season starts in February and continues till the end of October. The rainfall regime shows double maxima which is separated by a comparatively low rainfall period (dry period) in August called August Break. The length of wet season is at least seven months, i.e. about 220-250 days, with average rain days of 159. Temperatures are very high during day with cool night [4].

\section{Soil Preparation and Analytical Methods}

Soil samples were collected from four (4) locations within rain forest zone of Delta State, namely- Abraka, Sapele, Mosogar, Aghalokpe. These were chosen to reflect the differences in soil and vegetational characteristics.

Surface soils $(0-15 \mathrm{~cm})$ and sub-surface soils $(15-30 \mathrm{~cm})$ were sampled with a tabular sampling auger. Representative soil samples were taken and bulked for each depth and location. The samples were air-dried at room temperature depending on moisture content for two (2) weeks and crushed to pass through $2 \mathrm{~mm}$ mesh sieve. Sub-samples of soil from each location were further ground to pass through 100-mesh sieve for determination of organic matter. The rest samples were then analyzed for both physical and chemical properties of the soil.

\section{Soil analysis}

Soil samples were analyzed for physico-chemical properties as described by the International Institute for Tropical Agriculture [6] as follows:

a. Particle size Distribution: The analysis was done by the Hydrometer method as outlined by Juo [6].

b. Soil $\mathrm{Ph}: \mathrm{pH}$ was measured in water at ratio 1:1 (soil: water) by glass electrode $\mathrm{pH}$ meter [7].

c. Organic Matter: This was determined by wet dichromate acid oxidation method [8]. d. Exchangeable Bases: The soils ( $\mathrm{Ca}, \mathrm{Mg}, \mathrm{K}$ and $\mathrm{Na}$ ) were extracted with $0.05 \mathrm{~N}$ NH4OAc buffered at pH 7.0 [9]. Exchangeable $\mathrm{K}$ and $\mathrm{Na}$ contents of the extracts were read on EEL photometer. Exchangeable Ca and Mg were determined by titration method [6].

e. Total Exchangeable Acidity $(\mathrm{H}+, \mathrm{Al} 3+)$ : This was extracted with $1 \mathrm{~N}$ KLC [9] and determined by titration method $0.05 \mathrm{~N}$ $\mathrm{NAOH}$ using phenolphthalein as indicator.

f. Effective Cation Exchangeable Capacity (ECEC): The summation of exchangeable bases and total exchangeable acidity was taken as the effective cation exchange capacity value [10].

\section{Results}

The Physical and Chemical properties of the soils are presented in (Table1 \& 2)and the correlation coefficients ( $r$ ) relating the nutrient elements to one another are given in (Table 2).

Table 1: Physical Properties of Selected Soils of Delta State before Cropping.

\begin{tabular}{|c|c|c|c|c|c|}
\hline \multirow{2}{*}{ Sample Location } & Depth & \multicolumn{3}{|c|}{ Soil Properties } & $\begin{array}{c}\text { Textural } \\
\text { Class }\end{array}$ \\
\cline { 2 - 6 } & (cm) & Sand & Silt g/kg & Clay & \\
\hline \multirow{2}{*}{$\begin{array}{c}\text { Forest zone } \\
\text { ABRAKA }\end{array}$} & $0-15$ & 906 & 64 & 30 & S \\
\cline { 2 - 6 } & $15-30$ & 896 & 74 & 30 & S \\
\hline \multirow{2}{*}{ AGHALOKPE } & $0-15$ & 934 & 40 & 26 & S \\
\cline { 2 - 6 } & $15-30$ & 916 & 54 & 30 & S \\
\hline \multirow{3}{*}{ MOSOGAR } & $0-15$ & 911 & 49 & 40 & S \\
\cline { 2 - 6 } & $15-30$ & 901 & 49 & 50 & S \\
\hline \multirow{2}{*}{ SAPELE } & $0-15$ & 914 & 63 & 23 & S \\
\cline { 2 - 6 } & $15-30$ & 894 & 63 & 43 & LS \\
\hline
\end{tabular}

S: Sand; LS: Loamy Sand

Table 2: Chemical Properties of Selected Soils of Delta State before cropping

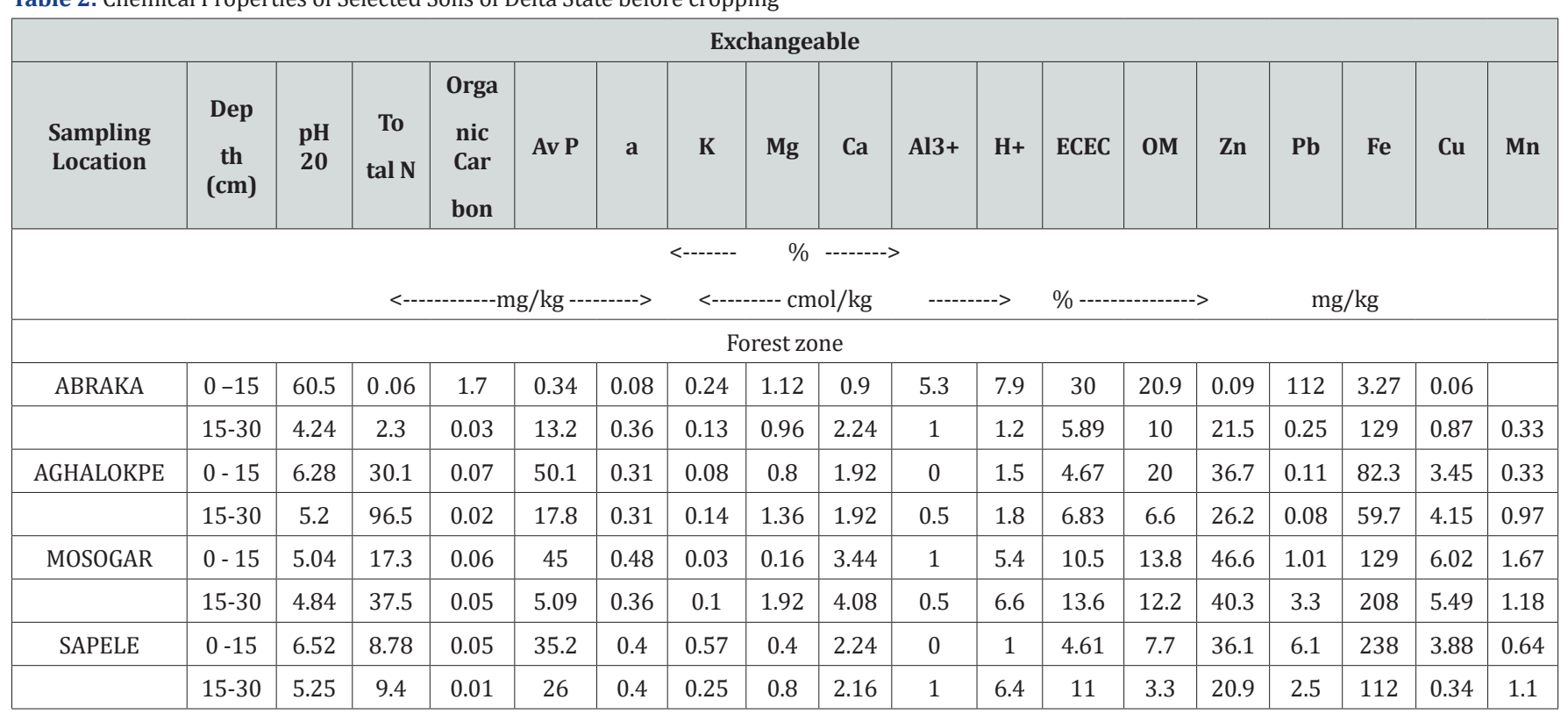


Av. P: Available Phosphorus; EC: Electrical Conductivity; ECEC: Effective Cation Exchange Capacity; OM: Organic Matter.

The texture of the soils varied from sand to loamy sand. Soil samples from K Abraka, Aghalokpe and Mosogar were found to be sandy at the topsoil and subsoil. Soil samples from Sapele were found to be sandy at the surface and loamy sand at the sub-surface (Table 1).

$\mathrm{pH}$ values of various locations ranged from 4.72 in Abraka to 6.52 in Sapele, that is, from strongly acidic to slightly acidic (Table 2). But at the subsurface, the pH ranged from 4.24 to 5.25; a similar range of moderately acidic to strongly acidic. The $\mathrm{pH}$ of the soils showed a decrease with depth with the exception of Aghalokpe and Sapele. At the two locations, Abraka (4.72) (rain forest) pH values were low when compared to the suggested pH level of 6-6.5 [11] for the production of most crops.

The percentage organic carbon values showed decrease with depth. At the surface it varied from $0.70 \%$ in Sapele to $1.73 \%$ in the soil from Abraka (Table 2). At the subsurface, the value ranged from $0.20 \%$ in Sapele to $0.77 \%$ in Mosoger using a critical value of $0.15 \%$ [9]. Abraka, Aghalokpe soils had moderate organic carbon content. Mosogar, Sapele, soils were low in organic carbon. Soil samples from all locations showed decrease with depth, reflecting lower content of organic carbon at $15-30 \mathrm{~cm}$ in comparison to $0-15 \mathrm{~cm}$. All locations had moderate organic carbon.

Total $\mathrm{N}$ content of the soils at all the locations ranged from $0.05 \%$ in Sepele to $0.07 \%$ in soil from Aghalokpe (Table 2) at the surface. At the sub-surface, it varied from $0.01 \%$ in Sapele to $0.05 \%$ in soils from Mosogar using a critical level of $0.15 \%$ [12]. The locations had moderate total nitrogen contents.

Available phosphorus for all the locations ranged from $35.2 \mathrm{mg} /$ $\mathrm{kg}$ in Sapele to $50.1 \mathrm{mg} / \mathrm{kg}$ in Aghalokpe at the surface (Table 2). This ranged from low to high, while at the sub-surface, the value ranged from 5.09 at Mosogar to $26.0 \mathrm{mg} / \mathrm{kg}$ at Sapele. Thus, indicating higher content of phosphorus in the surface soils in comparison with subsurface soils. Rain forest had high phosphorus content when compared to the established critical value of $17 \mathrm{mg} / \mathrm{kg}$ [13].

Exchangeable potassium for all the locations ranged from 0.03 to $0.57 \mathrm{cmol} / \mathrm{kg}$ in the surface and $0.10 \mathrm{cmol}$ to $0.25 \mathrm{cmol} / \mathrm{kg}$ in subsurface. In the surface soils, it was lowest in Mosogar, followed by Abraka and Aghalokpe while it was highest in Sapele. In the subsurface, the value was highest in the soils from Sapele, based on a critical value of $0.24 \mathrm{cmol} / \mathrm{kg}$ [14], surface soils obtained from Sapele were sufficient in exchangeable potassium while the other locations were deficient. Rain forest locations were deficient in exchangeable potassium.

Exchangeable magnesium value ranged from 0.16 to $0.80 \mathrm{cmol} /$ $\mathrm{kg}$ at the surface, while at the subsurface, it ranged from 0.80 to 1.92 (Table 2). At the surface, the value was highest at Aghalokpe followed by Sepele and Abraka. Thus indicating lower magnesium at the surface in comparison to the subsurface. Based on the critical level of $1.9 \mathrm{cmol} / \mathrm{kg}$ [14], all the locations had moderate exchangeable magnesium content.

Exchangeable calcium values ranged from 1.12 to $3.44 \mathrm{cmol} / \mathrm{kg}$ at the surface depth, while at the subsurface it ranged from 1.92 to $4.08 \mathrm{cmol} / \mathrm{kg}$ (Table 2). At the surface depth, the value was highest at Mosogar followed by Sapele. Soil samples from Abraka, Aghalokpe, Mosogar and Sapele were found to be deficient in calcium compared to the established critical value of $3.80 \mathrm{cmol} / \mathrm{kg}$ [13].

Exchangeable sodium value ranged from $0.31 \mathrm{cmol} / \mathrm{kg}$ to $0.48 \mathrm{cmolkg}$ at the surface depth, while at the sub-surface, it ranged from $0.31 \mathrm{cmol} / \mathrm{kg}$ to $0.40 \mathrm{cmol} / \mathrm{kg}$ (Table 2). At the surface, the value was highest at Mosogar, while the value was lowest at Aghalopke.

\section{Soil Micronutrients}

Zinc content ranged from $20.9 \mathrm{mg} / \mathrm{kg}$ in Abraka to $46.6 \mathrm{mg} / \mathrm{kg}$ in Mosogar at the surface soils and from $20.9 \mathrm{mg} / \mathrm{kg}$ in Sapele to $40.3 \mathrm{mg} / \mathrm{kg}$ in Mosogar at the sub-surface soils. Iron content ranged from $82.3 \mathrm{mg} / \mathrm{kg}$ in Aghalokpe to $238 \mathrm{mg} / \mathrm{kg}$ in Sapele at the surface soils and from $59.7 \mathrm{mg} / \mathrm{kg}$ in Aghalopke to $208 \mathrm{mg} / \mathrm{kg}$ in Mosogar at the sub-surface. The critical value of iron and zinc have been given as $3-4.5 \mathrm{mg} / \mathrm{kg}$ [11] and 5-9mg/ $\mathrm{kg}$ [15], respectively. In considering the level above, the soil could be considered to be high in Fe and Zn contents.

The lead content ranged from $0.09 \mathrm{mg} / \mathrm{kg}$ in Abraka to $6.10 \mathrm{mg} /$ $\mathrm{kg}$ in Sapele at the surface soils and from 0.08 in Aghalokpe to $3.30 \mathrm{mg} / \mathrm{kg}$ in Mosogar at the sub- surface soil. Copper content ranged from $3.27 \mathrm{mg} / \mathrm{kg}$ in Abraka to 6.02 in Mosogar $\mathrm{mg} / \mathrm{kg}$ in the surface soils and from $0.34 \mathrm{mg} / \mathrm{kg}$ in Sapele to $5.49 \mathrm{mg} / \mathrm{kg}$ in Mosogar at the sub-surface soils. The values were low when compared to the average critical level of $6.35 \mathrm{mg} / \mathrm{kg}$ [16].

Available manganese content of the soil ranged from $0.06 \mathrm{mg} /$ $\mathrm{kg}$ in Abraka to $1.67 \mathrm{mg} / \mathrm{kg}$ in Mosogar for sub-surface soils. These values were low when compared to the established critical values of $10.3-15.7 \mathrm{mg} / \mathrm{kg}$ [17].

\section{Discussion}

An analysis of soils in the area of study showed that they ranged from sand to loamy sand. This textural class is accounted for by the low clay and silt contents in the area of study. This indicates that the rate of water infiltration in these soils may be high and, consequently, that the water holding capacity of these soils may be low. These properties could predispose soils to erosion, particularly, that rain forest zone in Delta state is high. The infertile nature of the soil could lead to low crop yields, if fertilizers are not applied; and resoure - poor farmers will be unable to meet crop demands. All that is required is to sustain the fertility of the soils and modify or improve on them (Agboola and Unamma, 1991). Rain forest zone of Delta State is a high rainfall area. The soils were acidic with low total nitrogen, available phosphorus, exchangeable potassium and calcium.

Southwestern Nigerian soils have been reported to be mostly sandy and loamy sand owing to the nature of parent materials which are predominantly sedimentary (Agboola and Unamma, 1991). Soils 
become acidic as a result of organic matter decomposition and by the addition of ammonum (NH4) nitrogen fertilizer. The hydrogen ions produced by these processes displace calcium, magnesium and potassium from the surface of the soil particles. These free salts are then leached from the upper regions of the soil profile by water moving downward through the soil [18]. The mean pH was 5.2 in Rain forest zone. This is suitable for crop production in Nigeria [19]. The nutrient status of the soils was generally low with most of the nutrients having concentrations below the critical limits. Organic carbon content was sufficient at all locations according to the critical value of $1.0 \%$ recommended by Agboola \& Ayodele [14]. Total N, available P and exchangeable K were marginal at all locations based on the recommendation by FDALR [12]. Calcium was deficient at all locations while Mg was marginal in rain forest zone of Delta State [19].

\section{Conclusion and Recommendations}

The determination of the physical and chemical properties of the rain forest zone of Delta State was the principal objective of this study. Soil analysis to determine the levels of plant nutrients in the soils was carried out [20-25].

Consequently, the results from this study could be summarized as follows:

1. Soils of the area of study were mainly sandy loam.

2. The soils of the area of study had suitable $\mathrm{pH}$, marginal nitrogen, exchangeable calcium, magnesium and ECEC.

The soils were sufficiently supplied with micro-nutrients; especially, zinc, lead, iron, copper and manganese. However, the soils are deficient in available phosphorus and exchangeable potassium.

It is therefore recommended that phosphorus and exchangeable potassium should be artificially supplemented for growth and yield of crops needing higher level of these nutrients.

\section{References}

1. Ayeni LS, Adeleye EO (2011) Soil nutrient status and nutrient interactions as influenced by agro wastes and mineral fertilizer in incubation study in the Southwest Nigeria. International Journal of Soil Science 6 (1): 60-68

2. Nkhuzenje H, Mughogho SK, Sakala WD, Saka AR (2002) Contribution of Promiscous and specific Soybean Varieties to Soil Fertility improvement and maize yield for Smallholder Farmers in Zomba District of Malawi.

3. Iloeji SI (2003) General Geography of Nigeria. Heinemann Books Ibadan.

4. Wikipedia (2006) The free encyclopedia.

5. Umeri C, Moseri H, Onyemekonwu RC (2016) Effects of Nitrogen and Phosphorus on the Growth Performance of Maize (Zea mays) in selected soils of Delta State, Nigeria. Advances in Crop Science and technology 4(1): 1-4.

6. IITA International Institute for Tropical Agriculture (1979) Selected methods for soils and plant Analysis Manual series No1 IITA.
7. Mclean EO (1982) Soil pH and Lime requirements. In: Page AL (Ed.), Method of soil analysis. Part 2 Agronomy 9. ( $2^{\text {nd }}$ edn), ASA and SSA Madison Wisconsin, USA, pp. 595-624.

8. Nelson DW, Sommers LE (1982) Total carbon, organic carbon and organic matters. In: Page et al, (Ed.), Method of soil analysis part 2. Agronomy 9 ( $2^{\text {nd }}$ edn), ASA and SSA Madison Wisconsin, USA, pp: 595624.

9. Thomas GW (1982) Exchangeable cations In: Page AL (Ed.), Method of soil Analysis part 2. Agronomy 9 ( $2^{\text {nd }}$ edn), ASA and SSA Madison Wisconsin, USA, pp. 595-624.

10. Okalebo JR, Gathua KW, Woomer PL (2002) Laboratory Methods of Soil and plant Analysis: A working Manual. ( $\left.2^{\text {nd }} e d n\right)$, TSBF-CIAT and SACRED Africa, Nairobi, Kenya.

11. Agboola A, Ayodele O (1985) Soil test for upland rice in Southern western Nigeria. Fertilizer Research 14(3): 227-234.

12. FDALR (Federal Department of Agric land Resources) (2004) Handbook on Soil Test- Based Fertilizer Recommendation for Extension Workers. National special programme for food security, p. 39.

13. Agboola AA, Corey RB (1993) Soil Test Calibration for NPK for Maize. Journal of West Africa Science Association 17: 93-100.

14. Agboola AA, Ayodele O (1987) Soil Test for Upland Rice in Southwestern Nigeria. Fertilizer Research 14: 227-234.

15. Sillanpaa M (1972) Trace elements in soils and Agriculture Soils Bulletin 17: 67.

16. Chude VO, Obigbesan GO (1980) Federal Ministry of Agriculture and Natural Resources (FMANR). (1990) Literature Review on Soil Fertility. Investigation in Nigeria, Nigeria, pp. 170-173.

17. Ayanlaja SA (1983) Soil and Agro meteological Studies on Cocoa CRIN Annual Report.

18. Naidu R, Syers JK, Tillman RW, Kirkman JH (1990) Effect of liming and added phosphate on change characteristics of acid soils. Soil Journal Soil science 41: 157-164.

19. Lawal BA, Ojanuga AG, Isada PA, Mohammed TA (2013) Characterisation, Classification and Agricultural Potentials of Soils on a Toposequence in Southern Guinea Savanna of Nigeria. World Academy of Science Engineering and technology. International Journal of Biology, Veterinary, Agricultural and Food Engineering 7(5):146-150.

20. Agboola SA (1968) Patterns of Food Crop Production in Southwest Nigeria. Geographical Journal11 (2): 135-152.

21. Bremmer JM, Mulvaney CS (1982) Nitrogen- total In: Page AL (Ed.), Method of soil analysis Part 2. Agronomy 9. ( $2^{\text {nd }}$ edn), ASA and SSA Madison Wisconsin, USA, pp. 595-624.

22. Bouyoucos GH (1962) Hydrometer Method of Making particle Size Analysis of Soils. Soil Science Society Annual Proceeding 26: 264-265.

23. Murphy J, Riley JP (1962) A modified single solution method for the determination of phosphorus in natural water. Analytica Chimica ACTA 27: 31-36.

24. Olsen SR, Sommers LE (1982) Phosphorous In: Page AL (Ed.), Method of soil analysis part 2. Agronomy 9 ( $2^{\text {nd }}$ edn $)$, ASA and SSA Madison Wisconsin, USA, pp. 595-624.

25. Udo EJ, Ogunwale JA (1986) Laboratory manual for Analysis of Soil, Plant and Water Samples. Department of Agronomy, University of Ibadan, Ibadan, Nigeria, pp. 45-47. 
This work is licensed under Creative Commons Attribution 4.0 License DOI: 10.19080/ARTOAJ.2017.05.555668

\section{Your next submission with Juniper Publishers will reach you the below assets}

- Quality Editorial service

- Swift Peer Review

- Reprints availability

- E-prints Service

- Manuscript Podcast for convenient understanding

- Global attainment for your research

- Manuscript accessibility in different formats

( Pdf, E-pub, Full Text, Audio)

- Unceasing customer service

Track the below URL for one-step submission https://juniperpublishers.com/online-submission.php 